\title{
LAND MANAGEMENT PROBLEMS IN NEPAL: REPERCUSSIONS OF LAND USE POLICY AND IMPLEMENTATION GAPS IN REGIONAL AND URBAN PLANNING
}

\author{
B. J. K. Chand \\ PESO Consultants (P) Ltd., Kathmandu, Nepal - bisuddhi@gmail.com \\ Commission V, WG V/7 \& Commission IV, WG IV/6
}

KEYWORDS: Land Management, Land Use, Policy and Implementation, Land Development, Regional and Urban Planning

\begin{abstract}
:
In lieu of advancement in human civilization from nomadic age to quest for welfare capitalism in recent days, land resources have been one of the most sought after assets for subsequent socio-economic development. The concept of land, once only geo-political has evolved to be interdisciplinary with developmental and managerial aspects in regional and urban planning worldwide making the facets of land management more complex than ever. In the context of modern Nepal, governance in systematic land management appeared during mid-1960 only with establishment of Ministry of Land Reform (MoLR). This paper aims to provide constructive criticism upon institutional fragmentation, and fragile policy and implementation gaps in land use administration which have been bewildering the concepts of regional and urban planning in Nepal. The recitation of this work is primarily based on selected literature review of relevant research on land use planning along with two representative case studies in national context and in international scenario as well. Despite rigorous efforts, the issues of competence in land administration, migration and syndicate in urban real estate remain as the major problems in land management in Nepal. Also, the new state restructuring of federal Nepal has already upraised the challenges in land resources planning for local governments who but seem muddled up in constructing rural economy and strategic urban plan for regional development. Nevertheless, these concerns in regional and urban planning can be addressed through practice of sustainable land management with thoughtful consideration of ambiguities in land use policy and implementation.
\end{abstract}

\section{INTRODUCTION}

As a definite property, land resources have economic as well as physical definitions varying from geological resources to biodiversity. Essentially, land has a spatial dimension which offers point of departure in development planning resultant to regional and urban planning. In both the concept of regional and urban planning, land use management is mutually associated with development of growth centres and built environment of a particular urban or urban-oriented areas. In global pursuit of Sustainable Development Goals (SDGs), almost 10 out of 17 goals are directly or closely related to features of land resources, of which 6 goals again indicate interdependence in important facets of regional and urban planning (UN, 2019). In this interdisciplinary context, land management becomes the key tool in achieving shared goals. This relates to the areas of providing the relevant geographic information in terms of mapping and databases of the built and natural environment, and also providing secure tenure systems, systems for land valuation, land use management and land development (Enemark, 2010).

\subsection{Status of Land Management in Nepal}

Although the conventional system of land management in Nepal dates back to 1870 s, regulatory means for land management in modern Nepal was lately introduced in 1962 only with formulation of Land Survey and Measurement Act (MoLCPA, 2019). The Ministry of Land Reform and Management has featured 62 acts being related to land management, among which at least eight acts are directly related with land management issues (MoALC, 2018). Recently, Government of Nepal has passed a bill related to land use which again may have some inconsistencies in regard to regional and urban planning sector.

In this preface of land use management, it is necessary to understand the characteristics of land cover in Nepal. Again, the perspective of land cover fulfills with the concept of land use only. Recalling the implementation of land use policy in Nepal, National Land Use Project was set up in 2000. One of the major objectives of the project was to identify and zoning the land for housing, urbanizing, industrialization and other non-agricultural processes in the existing municipalities and urban-oriented rural areas as well as to balance the environment and sustain the system by preserving and developing water, forest and living treasure. But the much needed Land use Act 2019 came forth retrospectively in September 2019 only.

In current scenario, land cover dynamics of Nepal ranges from $44.47 \%$ enclosed by forests to $1.15 \%$ occupied by built-up areas (Forest Research and Training Centre, 2019). The land cover data shows that while $28.68 \%$ of land is spared to bare soil, rock, ice and other unmanaged land, only $21.88 \%$ of land is occupied by arable and tillage land and agro-forestry systems. Likewise, $2.60 \%$ of land is swamped by grasslands and $1.22 \%$ of land is reserved by wetlands.

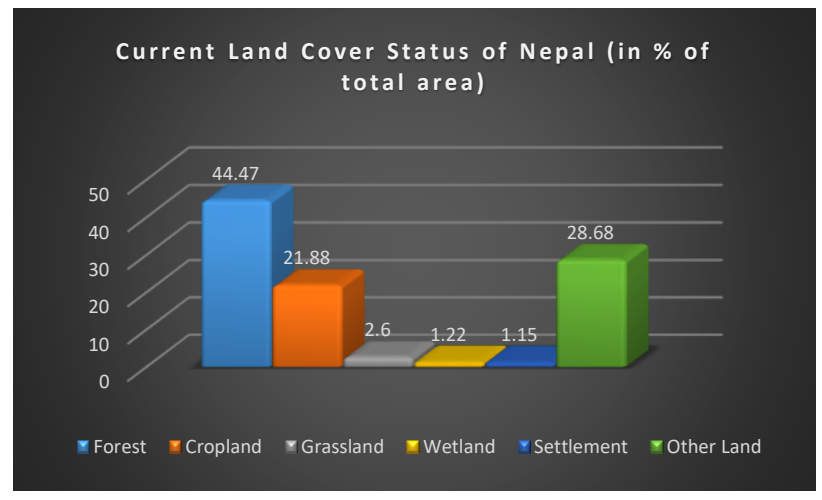

Figure 1. Current land cover status of Nepal. (Source: Forest Research and Training Centre, 2019) 
The newly formulated Land use Act 2019 features formation of Land use Council in federal, provincial and local levels of governments. It suggests preparation of land use program including 11 different areas such as: industrial corridors, special economic zones, national projects, inter-provincial projects, protectable natural and physical heritages of national importance, places of religious and cultural importance bearing international identity and humanitarian beliefs, school or other educational areas, roads, health institutions, areas with irrigation canal, sensitive areas in terms of national security, areas having disaster risk, protected areas for environmental cleanliness and bio-diversity conservation, and other required areas (House of Representatives Nepal, 2019).

In the Act, several legal provisions has also been advised for upgrading land records and administration system, determination of land taxes and valuation, change in land use and restrictions in fragmentation of land. Hopefully, the Land use Act has introduced an enthusiastic concept of land bank in land management. On the other side, the government is still struggling to expand its capacity in offering digital land surveying and administration services to general public.

\subsection{Directions in Regional and Urban Planning in Nepal}

Ironically, Nepal is both the least urbanized country in South Asia, with about $17 \%$ of its population living in urban areas, and the fastest-urbanizing country, with an average urban population growth rate of about $6 \%$ per year since the 1970s (Muzzini, Aparicio, 2013). But, with new state restructuring of federal Nepal, it is ambiguously depicted that the country constitutes around $50 \%$ of urban population pertaining to politicoadministrative definition of urban and rural municipalities, and these singularities truthfully present the fabrication in regional and urban planning in Nepal.

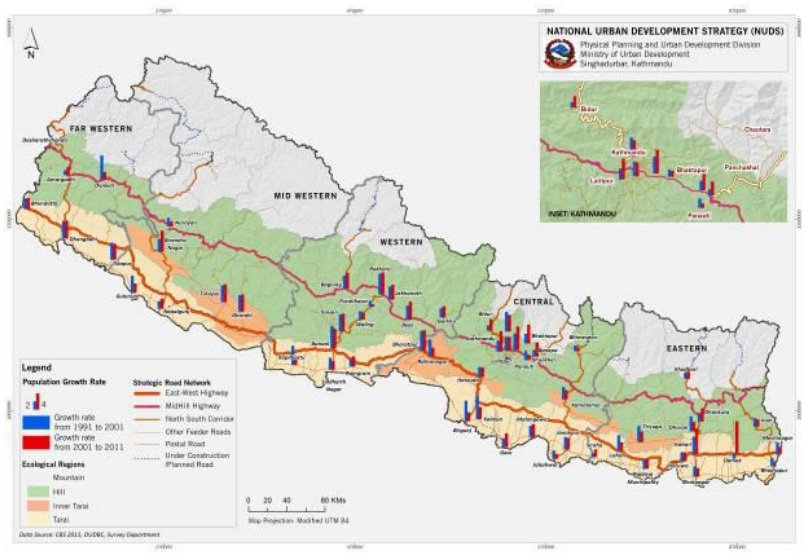

Figure 2. Urban population growth rate of Nepal. (c) NUDS, 2017

The concept of planned development in Nepal was introduced in 1955 with the preparation of draft outline of the First Five Year Plan (1956/57 - 61/62), and the model of modern urban planning came in Nepal in 1964 with the arrival of Austrian architect Carl Pruscha via United Nations Development Program (UNDP) assistance (Carl Pruscha, 2019). In the Fourth Five Year Plan (1970/71 - 75/76), approaches of regional planning were adapted in Nepal based on the concept of growth poles and growth axes which was followed by the formulation of District Administration Plan in 1974. For the first time, the Eighth Five Year Plan (1992/93 - 96/97) had a separate chapter on urban development aimed at regional balance. Then came the Three
Year Interim Plan in 2007 constructed in heavy interaction programs on the draft of the approach paper held at local and regional levels. Several experts on different subjects prepared working papers and gave suggestions to the National Planning Commission (NPC) which unfolded the deep-rooted causes of underdevelopment in Nepal (Joshi, 2008). Then after, Nepal has seen its regular periodical plans, among which the most noticeable ones are the National Land use Policy documented in 2013 and the National Urban Development Strategy (NUDS) framed in 2017 after several years of study.

The basis of NUDS arose not only from the desire to operationalize National Urban Policy (NUP) and build consensus on the definition of the term urban development, but other multiple factors embedded to the urban development sector also demanded this. These factors among others include skewed growth of the Kathmandu Valley overriding the balance of regional cities and towns, haphazard urbanization, infrastructure gaps, deteriorating natural and built environment, inability of urban areas to generate economic opportunities, fragmented urban governance, and insubstantial revenue of the local bodies. NUDS envisages urban development as an endeavor of spatial and physical development which is the fundamental basis for sustainable social, economic and cultural development vis-à-vis environmental management (MoUD, 2017).

In an overview of regional and urban development in Nepal, issues of land use policy and approaches for regional and urban planning are explicitly not mutually exclusive. Difficulties in land management has instinctively become special problem in spatial planning in rural and urban areas of Nepal, and in reciprocal means, the later has instigated new challenges in land governance thereafter. Therefore, a dialectical process is necessary to examine and address the uninvited hurdles in the path of both sustainable land management and sustainable urban development.

\section{THE COMMON DENOMINATOR}

There is a well-known mathematical principle that to simplify a given problem at hand, a common or mutual denominator is required. Similarly, here in case of problems in land management, and regional and urban planning, we have land use as a common factor. Physical aspects of regional and urban planning are largely related to land use and development which itself is an indispensable aspect of land management and governance. In context of Nepal, statutory practice of land use and zoning regulations have not been implemented objectively in the apparatus of land administration which has shaped irregularities and invited challenges and problems in land management. Particularly, migration from rural to urban areas for various reasons and unusual investment in urban real estate has brought about terrible regional imbalance in national economy of Nepal which have confronted land use policies and regional and urban development strategies. In order to avoid these complications, we need to match legal provisions in land management with standard norms and values in regional and urban planning.

\subsection{Land use Planning in Nepal}

Land use is one of the inescapable aspects in land management for guide to effective planning of land resources in order to realize intentions of regional and urban development. Either in land reform policies or in land development plans, land use planning has remained as key of implementation measures in 
land administration in Nepal. As we look into periodic planning history of land management in Nepal, from 1960s to 70s during initial days of periodic planning in Nepal, reforms in land management were introduced with emphasis in agricultural productivity. Periodic plans of 1970 s and 80 s also intervened in land management systems mainly for conservation and protection of forestry and natural resources.

Major turn in land use planning in Nepal arrived with Eighth Five Year Plan (1992/93 - 96/97) which identified land use plan as a long-term basis program in order to address the problems in land management. The subsequent Ninth Five Year Plan (1997/98 2001/02) was focused in sustainable development for preservation and extension of ecological sectors of mountains, hills and lowlands using land and natural resources. It was followed by the Tenth Five Year Plan (2002/03 - 2006/07) with objectives of land use sector to create service-oriented and informative land administration by development of sustainable land use management for increasing land productivity (Sharma, 2012). Main objectives of above mentioned plans were to implement land use planning based on maps prepared at various levels and identification and classification of land for agriculture, forestry, industrialization and urban settlement extension. Formulation of land use policy, discouragement in use of arable land for non-agricultural purposes or unproductive activities, and development of National Geographic Information System was also envisioned by the five year plans. Almost in all later fiscal plans of Government of Nepal, one particular agenda has always found its place: formulation of an appropriate act related to land management or land use policy in order to stop use of potentially arable land in unproductive urban real state. This issue of land use is still in debate whilst National Land use Policy (NLUP) was formulated in 2013 which was repealed and a new Land use Policy (LUP) was adopted again in 2015 (MoLRM, 2015).

LUP 2015 has clearly stated in its background that in the context of Nepal, on account of fast growing population, internal migration, unmanaged and rapid urbanization, among others, encroachment over arable lands, forests, government and public lands, various natural resources is rampant these days, and the protection thereof has poised a challenge now (MoLRM, 2015). Policy No. 1 of LUP statuses classification of entire land of the country into 11 different land use zones (LUZs): agricultural zone, residential zone, commercial zone, industrial zone, mines and minerals zone, cultural and archaeological zone, river and lake-reservoir zones, forest zones, public use and open space zone, building materials (stone, sands, concrete) excavation zone, and other zones as specified as per necessity, for example, vulnerable/hazardous zones. While LUP promises to discourage the trend of keeping land fallow and rampant fragmentation it also envisions a hygienic, beautiful, well-facilitated and safe human settlement along with a planned and sustainable urbanization of the country.

To remember, the newly formulated Land use Act 2019 also has similar features comparing it to LUP 2015. But, there exists incoherence in some parts of both the policy and act making it susceptible to being less comprehensive. Despite the fact that numerous land management acts and regulations have emphasized on public awareness on land use and the long-term impact thereto, there lacks sufficient co-ordination beforehand among and between interdisciplinary institutions and local stakeholders regarding the subject and content of proposed bills on land use planning resulting to complications in its effective implementation.

\subsection{Land use Norms and Standards in Planning Practice}

Be it a small scale project of rural infrastructure development in small towns or a new town development project aimed at urban land development, land use norms and standards are crucial parameters in implementation of the concerned project. Development planning is intended to guide appropriate land use pattern and vice versa in foundations of planning practice. Fundamentally, regional and urban planning method is anticipated so as to follow the process in which land asset is considered a primary tool. In the process, land is first equipped with proper services or facilities as a prerequisite for proposed infrastructures to be built. Then only comes the ownership of the infrastructure by people, and the project is assumed to be operational. But in case of Nepal, the process is just the opposite wherein the socio-economic dimension of people or public usage comes first which attacks land assets secondly and the rest of development follows thereafter. This unusual phenomenon of unreasonable takeover in the process has emerged as a major problem in planning practice in Nepal.

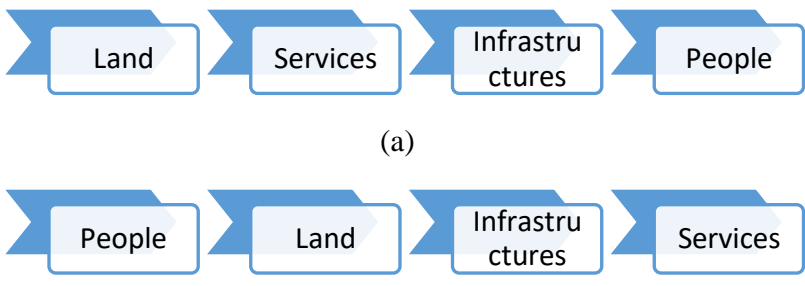

(b)

Figure 3. Flowchart showing intended (a), and involuntary (b) processes in planning method.

Framework for regional and urban planning in Nepal has become vague as there exists dilemma regarding whether the pattern of land use should be guided or decided by social institutions or the government agencies to implement it. As population is increasing due to aspirations of urban economy and also due to urban-oriented rural agglomerations, change in land use pattern is expected, especially mixed-use pattern are noticed at most. Rural areas are continuously evolving from agrarian societies to service-oriented and commercial economies, and at the same time, urban settlements are also seeking for expansion due to transformation in commercial and industrial sector triggered by development in means of transportation. This spontaneous occurrence has created transition in land use pattern in both rural and urban areas of Nepal. We need to wisely address this issue as the spatial arrangement of economic activities is not random, it is but the result of decisions made by our own social institutions including families, business, and government itself. Some of the factors determining land use are: land use plans and maps, infrastructure, information system, zoning, bye laws, building codes and conservation, budgeting and fiscal incentives, population, demand for land for different uses, and territorial rights (Joshi, 2019).

Land use pattern is often guided by form and hierarchy of settlements. Human settlements in Nepalese context are sparsely populated in wide range with some rural municipalities having population around 15,000 to metropolitan cities accommodating population of approximately 1,000,000 (Central Bureau of Statistics, The World Bank, 2013). Given the skewed distribution of population in both rural and urban areas, delivery of basic services and facilities have also become unmanaged and unequal challenging regional and urban planning practice in 
Nepal. This has occurred mainly due to inaccuracies and complications in land use planning of above-mentioned disorganized settlements. Nevertheless, Government of Nepal (GoN) has tried to shape a path for sustainable urban development with some plans and projects of developing regional centers which would eventually disseminate the significance of land use planning.

One of the commendable steps by GoN towards setting up necessary codes in planning practice is preparation of Planning Norms and Standards in 2015. With an objective of facilitating urban designers, planners and policy makers to identify and forecast essential infrastructure need of urban areas, it asserts in understanding of urban form and land use in order to ensure balance between them with recommendation of land use norms and standards (MoUD, 2015). It has arranged a hierarchy of urban areas into 5 classes: metro city, sub-metro city, city, subcity, and market center which are based on population and guided by infrastructure, land use and urban form.

\begin{tabular}{|l|l|l|}
\hline $\begin{array}{l}\text { S. } \\
\text { No. }\end{array}$ & $\begin{array}{l}\text { Broad } \\
\text { Classification }\end{array}$ & Sub-classification \\
\hline 1. & $\begin{array}{l}\text { Natural } \\
\text { Resources } \\
\text { Area (60\%) }\end{array}$ & $\begin{array}{l}\text { Agricultural forest/Community } \\
\text { forest/Water bodies }\end{array}$ \\
\hline 2. & $\begin{array}{l}\text { Settlement } \\
\text { Promoted } \\
\text { Area (40\%) }\end{array}$ & $\begin{array}{l}\text { Mixed (Residential cum } \\
\text { Commercial)/Residential/Institution } \\
\text { al (Office complexes)/Industrial } \\
\text { (Agricultural initial processing } \\
\text { industries that are linked to the } \\
\text { industries of the cities) }\end{array}$ \\
\hline
\end{tabular}

Table 1. Types of land use for Market Center. (c) Planning Norms and Standards, 2015

\begin{tabular}{|l|l|l|}
\hline $\begin{array}{l}\text { S. } \\
\text { No }\end{array}$ & $\begin{array}{l}\text { Broad } \\
\text { Classification }\end{array}$ & Sub-classification \\
\hline 1. & $\begin{array}{l}\text { Natural } \\
\text { Resources } \\
\text { Area (40\%) }\end{array}$ & $\begin{array}{l}\text { Urban agriculture/Water } \\
\text { bodies/Open spaces/Public land }\end{array}$ \\
\hline 2. & $\begin{array}{l}\text { Settlement } \\
\text { Promoted } \\
\text { Area (60\%) }\end{array}$ & $\begin{array}{l}\text { Mixed (Residential cum } \\
\text { Commercial)/Residential/Rural } \\
\text { residential/Commercial/Institutional/ } \\
\text { Industrial (Production with heavy } \\
\text { processing)/Recreational/Park }\end{array}$ \\
\hline
\end{tabular}

Table 2. Types of land use for City.

(c) Planning Norms and Standards 2015

\begin{tabular}{|l|l|l|}
\hline $\begin{array}{l}\text { S. } \\
\text { No. }\end{array}$ & $\begin{array}{l}\text { Broad } \\
\text { Classification }\end{array}$ & Sub-classification \\
\hline 1. & $\begin{array}{l}\text { Natural } \\
\text { Resources } \\
\text { Area (30\%) }\end{array}$ & $\begin{array}{l}\text { Urban agricultural area/Water } \\
\text { bodies/Recreational areas/Open } \\
\text { spaces/Public land }\end{array}$ \\
\hline 2. & $\begin{array}{l}\text { Settlement } \\
\text { Promoted } \\
\text { Area (70\%) }\end{array}$ & $\begin{array}{l}\text { Urban core area/Mixed (Residential } \\
\text { cum Commercial)/Commercial/High } \\
\text { residential/Medium residential/Low } \\
\text { residential (Rural)/Urban expansion } \\
\text { area/Institutional/Industrial } \\
\text { (Service-oriented: } \\
\text { Tourism/IT/Logistic/Display, } \\
\text { etc.)/Heritage/Religious }\end{array}$ \\
\hline
\end{tabular}

Table 3. Types of land use for Metro City. (c) Planning Norms and Standards, 2015
As suggested by the Planning Norms and Standards 2015, the land use is basically categorized under natural resources promoted area and settlement promoted area. The norms for the land use for urban areas explains the types of specific uses allowed with each land use and the percentage adequate for each land use whereas standards explains the specific standards for each land use such as distances from the main road, water bodies, minimum land parcel sizes, etc. which govern the form of the urban areas. The percentage for the allocation of natural resources and settlement promoted areas in the hierarchy of urban areas differ from $55-80 \%$ and $20-45 \%$ respectively. The percentage of natural resources and settlement promoted areas have been set in reference to the existing urban form, but since the built-up areas for the urban areas of Nepal is quite less, the percentage of settlement promoted areas has been taken with consideration to other developing countries.

\subsection{Cross-cutting Issues and Repercussions}

After a brief introduction of land use planning in Nepal and land use norms and standards in planning practice in singularity, the embedded problems in land management in Nepal related to regional and urban planning has come to surface. It is evident that the cross-cutting issues are around land use planning, yet another hidden factor to be considered is the attitude of both government and general public in acceptance of the plans and policies related to land management. For the government, problems in land management seems to be sole concern of MoLCPA whereas challenges in regional and urban planning are directed to Ministry of Urban Development (MoUD). In the formation process of relevant strategies, other ministries and departments are dodged. Sometimes, plans and policies on land management and development come indifferent to overlapping agencies which are short of adequate participation and feedback from general public and local stakeholders. In some cases, guidelines are drafted along with participatory planning process, which are again surprisingly not acknowledged by the general public.

For instance, MoLCPA has initiated a program, Freed Agricultural Bonded Laborer Rehabilitation Program (FABLRP) which provides a parcel of land or new housing or financial aid for maintenance of existing houses of the laborers. But, the beneficiaries are not ready to move to allotted sites rather they insist that a housing plot be allocated for them in market centers where the housing conditions are already in chaos.

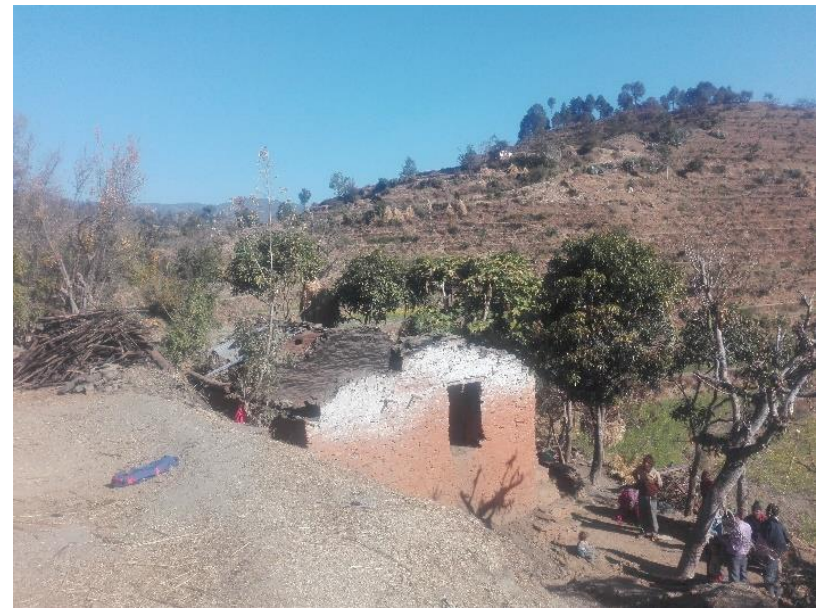

Figure 4. A selected house of a beneficiary of FABLRP in rural hills of Dadeldhura district. 
It is sometimes a matter of utter disgrace that stories of corruption in selection of land parcels are heard wherein both the government officials and beneficiaries, and land brokers are involved. This has challenged the both the aims of government to alleviate poverty and set up planned settlements in rural areas of Nepal.

Also in case of urban poor, back in 2012 Department of Urban Development and Building Construction under MoUD purchased 4,070 square meters of land from Ichangu Narayan Land Pooling Committee and built 227 housing units in 2014 for squatters and urban poor residing in informal settlements along the Bagmati River in Kathmandu Valley which amounted NRs 230 million to GoN (The Kathmandu Post, 2019). But in vain, the housing complex has remained vacant for almost five years as the squatters are reluctant to move in. In a case study of land readjustment of Ichangu Narayan Housing Project (Shrestha et al. 2017), the research concluded that there lacked participation of landowners in the planning process, and also there was lack of policy implementation of accommodating low-income groups. On the other hand, a similar housing project in Kirtipur led by a non-government organization, Lumanti, is reported to be successful. This tragedy in urban housing has raised some serious issues of institutional fragmentation among MoLCPA and MoUD in implementation of sustainable land management in urban context.

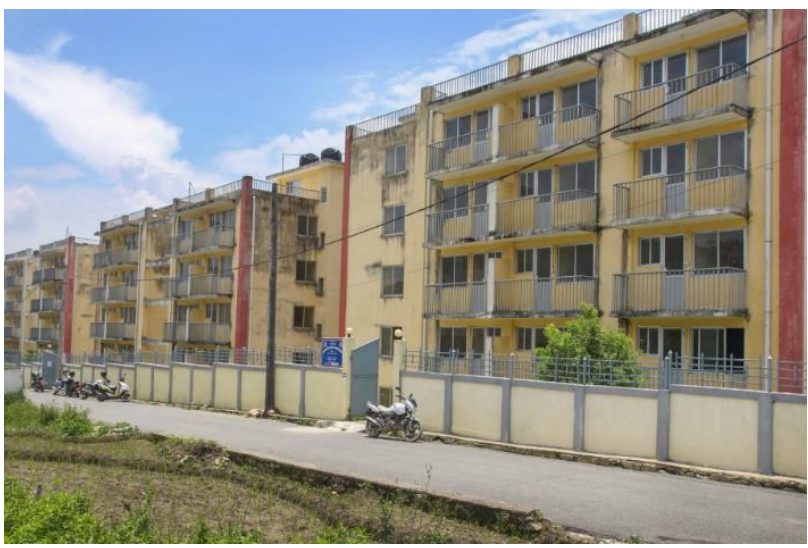

Figure 5. Abandoned Ichangu Narayan Housing Project for urban poor

(C) Tsering D Gurung/The Kathmandu Post, 2019

Besides the examples of small projects in rural and urban context, there are similar tragedies in various national level projects deemed crucial in the context of regional and urban planning in Nepal. As GoN is planning several new towns across the nation, it has introduced the concept of smart city development at different places. It is ridiculous to know that while the government is lagging behind in preparing proper land use plans and integrated urban development plans for various municipalities, it has declared ambitious program for smart cities void of justified indicators for smartness of a city. Without preplanning, it is unsure of managing smart cities, but with stubborn nature of government in co-ordination among inter-linked organizations in fields of regional and urban planning, it is more than sure that we are going to get dumb cities.

Also in case of new town development projects, the outcomes are uncertain if they would fulfill the objective of controlling internal migration from rural regions to urban areas. GoN has conceptualized that the developed new towns would consequently accommodate a population of 100,000 with adequate urban amenities and services. However, due to difficulties in land accquisition and abnormal delays in prerequisite infrastructure set up, targets of achieving regional balance seem faraway. In lack of appropriate land management and land administration in the project areas of new town development, people are unwilling to avail land for development, rather they are holding or involved in brokerage and trading of lands for speculation purpose. This has been unnecessarily appending the project and people are continuosly moving to near urban areas with better economic opportunities which has retrospectively triggered internal migration.

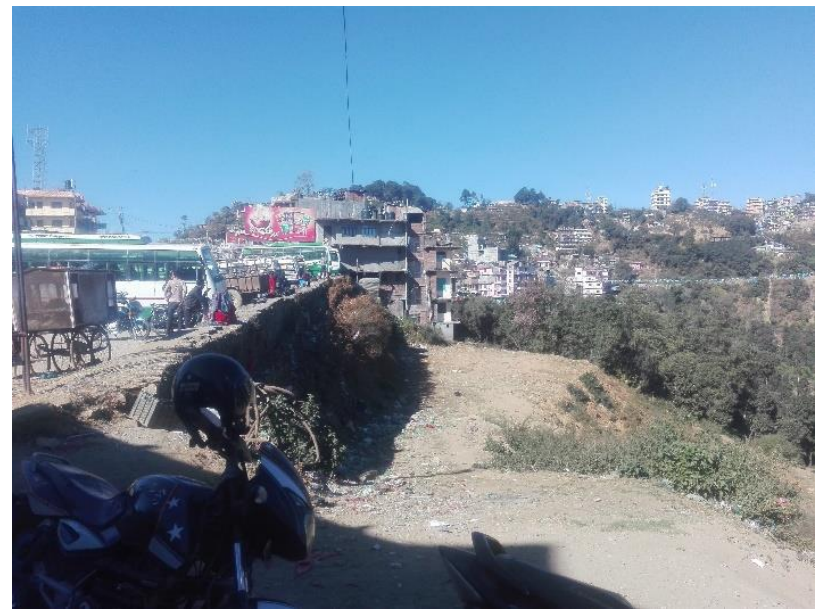

Figure 6. Unmanaged bus park area in BagBazaar of Amargadhi Smart City in Dadeldhura district.

Another problem in both land management and spatial planning is encroachment of government and public open spaces. Previously, there was an autonomous Town Development Committee (TDC) in almost all municipalities which had some portion of land under its jurisdiction which was a kind of land bank for government and public purposes. In its planning provision, the land would be used for government institutions, community or urban service centers, bus parks, sports facilities, recreational parks, emergency operation centers, public open spaces, and etc.

Now with new state restructuring of federal Nepal, formation of all the TDCs have been revoked and its property has been transferred to respective municipalities. This annulment of TDCs might not be desirable, but in last years, even TDCs were convoluted in overpoweringly distributing much valued government and public lands to different persons or organizations for vested interests which was ruthlessly against the norms and values of TDCs themselves. It is hard to believe but there is no more government and public land left with local governments in Nepal for future development purposes.

Apart from the deterioration of government and public land from local authorities, public open spaces have been equally encroached by the general public. Lands of various religious trusts, protected areas such as national parks, grasslands and community forests have been overtaken by the squatters, victims of natural disasters including landslides and flood. These issues are often fabricated by political interests whereby nobody seems to suggest for proper land management solution for the affected ones. Not only the homeless or landless people, but people with tenancy of adequate land are also involved in intruding barren and fallow land around them. Building bye laws are followed with little or without consideration of legal provisions in most of 
the rural and urban municipalities. Public open spaces called as breathing spaces for adjacent settlements are of being squeezed by both the government and general public.

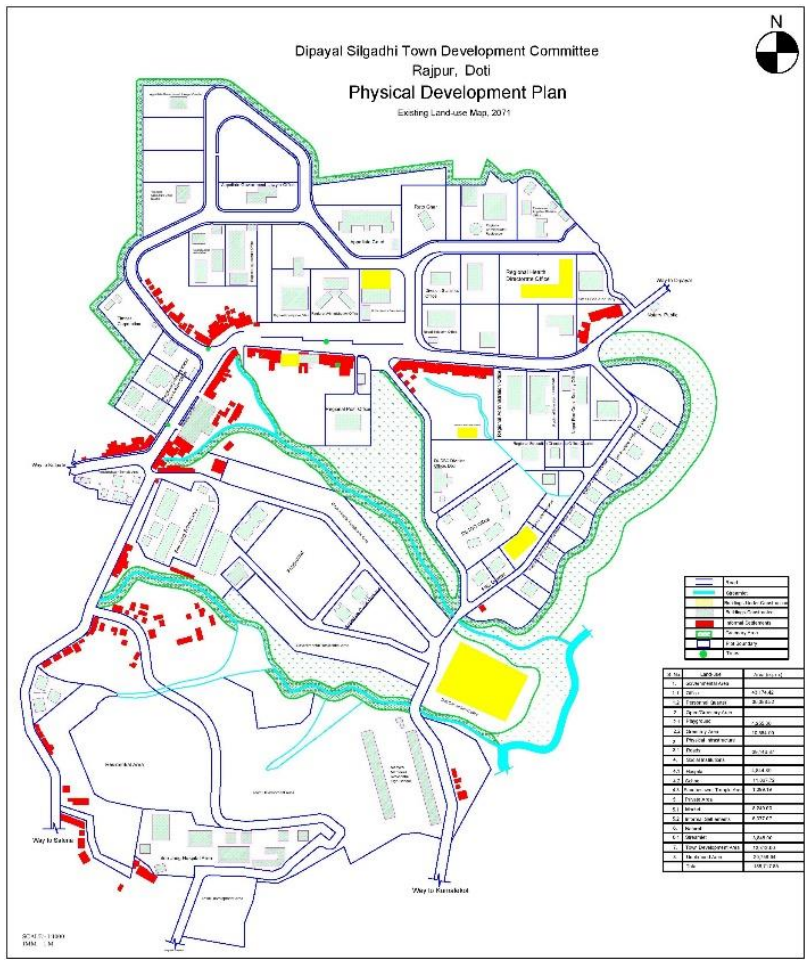

Figure 8. Land use Map with Physical Development Plan 2014 of Rajpur Governmental Area under Dipayal Silgadhi Town Development Committee in Doti district. (C) Bhupendra Jung Keshari Chand, 2019

\section{CASE STUDIES AND IMPLICATIONS}

The urgency of any problem is determined by its specific nature pertaining to its planning and implementation methodology. Also, in case of land management problems in Nepal, resolution lies within its policy and plan formulation and respective implementation thereafter. In modern days, traditional arm-chair planning has become almost outdated, and public participatory planning approach has emerged as a new paradigm in substantial result-oriented planning practice. In context of Nepal, Integrated Action Plan (IAP) is in exercise since long period of time whereby all the associated implementing agencies, partners and local stakeholders actively take part in the planning process from beginning of a project to its end. While the participatory planning process has come to be successful for many non-governmental organizations in Nepal, is has but become less effective in standings of government-initiated projects. It can be inferred from the government lead projects that decision-making is the key process wherein community participation is either kept in set back or the public themselves keep at distance during the process. With the help of some relevant case studies, fulfilment or fallacies in planning and implementation course can be well understood. A brief insight into both regional and international case studies in participatory land use planning and implementation project, and capacity building for sustainable land management would present some applicable findings in local as well as global perspective.

\subsection{Participatory Land use Planning and Implementation in Designated Districts of Nepal}

In 2015, a report on Participatory Land use Planning and Implementation (PLPI) in designated districts: Surkhet, Nawalparasi and Morang in Nepal was prepared by UN-Habitat Nepal in association with United Nations Development Program (UNDP) and International Organization for Migration (IOM) supported by UN Peace Fund Nepal (UNPFN) along with some local non-governmental organizations. The basic objective of the project was to carry out participatory land use planning and its implementation in the Latikoili, Amrout and Jhorahat Village Development Committees (VDCs) of Surkhet, Nawalparasi and Morang districts respectively and to assist in the compilation of legislative framework and land use planning and implementation guidelines for replicating participatory land use planning beyond project districts and VDCs. The project reportedly achieved 21 outcomes in preparation, data collection and analysis, land use planning, implementation of VDC land use plan, monitoring and evaluation, and capacity development and training (UN-Habitat Nepal, 2015).

The project was based on both top-down and bottom-up planning approach with technical or professional inputs and inclusive community participation. It also formulated district level land use plans of Surkhet, Nawalparasi and Morang districts in accordance with NLUP 2013 which provided a periodic vision on addressing the needs of rezoning or reallocation of land resources resulted by increase in migration, urbanization, industrialization, unplanned settlements, agro-farming systems, and use of forestry in respective districts. The report has strongly asserted on necessity of integrating district land use plan along with long-term or periodic development plan and annual development plan of the district by respective District Coordination Committees (DCCs).

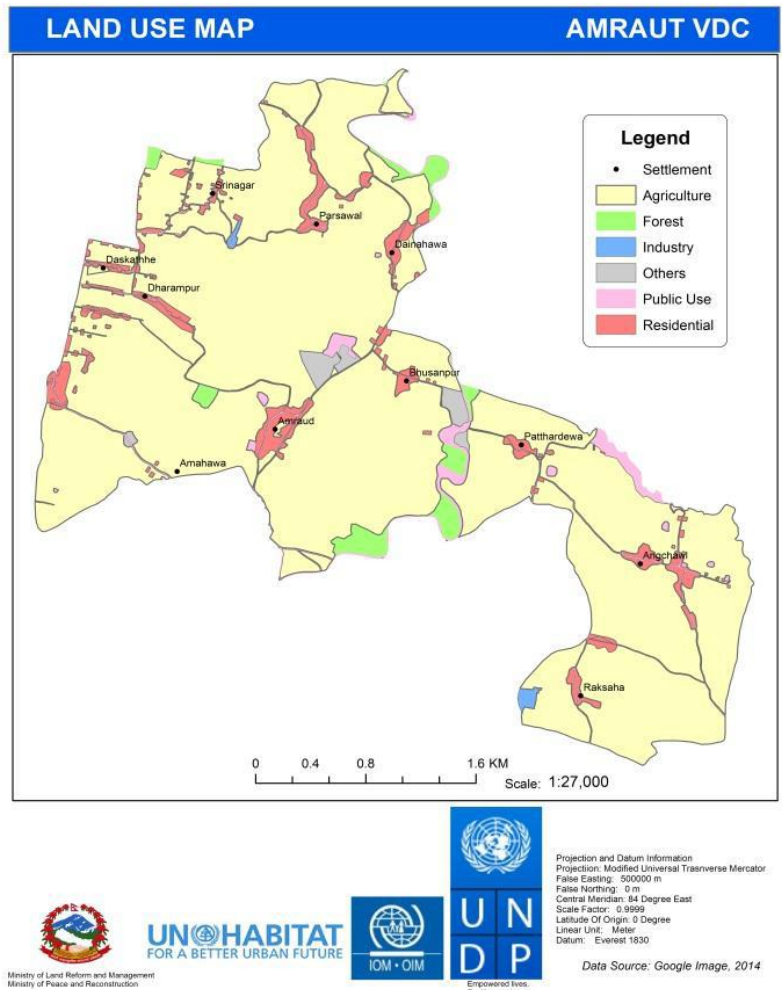

Figure 9. Land use Map of Amraut VDC. (c) UN-Habitat Nepal, 2015 
Land use plan of selected VDCs were prepared by using participatory planning approach with rigorous involvement of community and local stakeholders. The project prepared compiled land use maps including zoning maps, soil map, land capability and suitability map, cadastral superimpose and planning maps, also presented alternatives to sustainable land management such as land consolidation which were submitted to local Land Revenue Office and Survey Office as well.

\subsection{The Governance of Land use in the Netherlands: The Case of Amsterdam}

Apart from issues of capacity building and participatory planning approach in land management, ineffectuality in regional and urban planning across the globe has emerged as one of the major contests for land use planning. Similar could be the case in devising appropriate governance for land use in the Netherlands. Amsterdam, in the Netherlands along with its adjacent municipalities, have great regional as well as economic importance. Currently, dynamic growth of Amsterdam City has been asking for mixed-use and multiple land use pattern otherwise which would create chaos in urban housing and further expansion of the city. Also, transforms in transportation and rising tourism industry in urban core of Amsterdam has been challenging land uses of the city.

However, it is more than fulfilling to know that the Netherlands has self-binding strategic spatial plans for each level of government. The Spatial Planning Act 2008 is the main framework legislation for any sort of spatial planning in the Netherlands where structure plans and land use plans are the two major types of spatial plans. Again, the structure plans are selfbinding meaning that the plans of an upper level government are not legally obligatory on that of a lower level government. This provision makes the framework documents flexible in order that they can serve the needs and interests of each level of government and community as it requires (OECD, 2017).

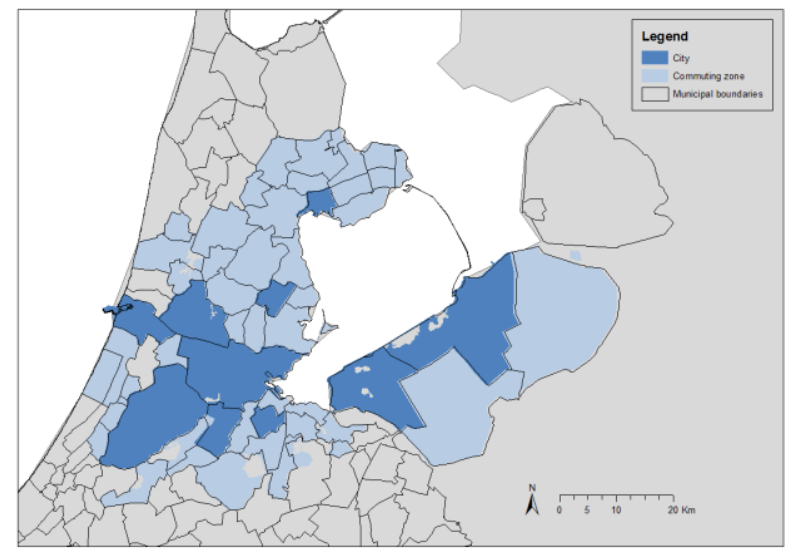

Figure 10. Amsterdam Functional Urban Area. (C) The City of Amsterdam

The national structure plan of the Netherlands constitutes a strategic spatial vision for development, on the very basis of which the national government used to intervene in urban planning by determining percentages of built-up areas in city cores, and outlining national buffer zones for implementing restructure plans. But with recent changes in governance of land use in the Netherlands, the national government only focuses on urban transportation system, and acts in accordance with local and regional authorities. The structure plan of Amsterdam city envisions radical spatial development of its land with objectives of encouraging urban population, expansion of mixed-use zones, and enhancement of quality of public open spaces guided by legal instruments of land use plans with active planning method. There is a new framework legislation in development in the Netherlands anticipated to come with integration of multiple rules and regulations mutually related to governance of land use such as natural resources, water bodies, real estate, and etc. which would ultimately facilitate the decision-making process in spatial and urban development projects.

\subsection{Policy and Implementation Gaps}

It is a coincidence that major turn in both land management system and in regional and urban planning in Nepal emerged simultaneously along with the Eighth Five Year Plan (1992/93 96/97) which identified land use plan as a long-term basis program in order to address the problems in land management, and it also had a separate chapter on urban development aimed at regional balance. Despite having a fate of twin policies from single periodic plan, consecutive developments in plans of land management and that of regional and urban planning seem to have taken different paths in singularity.

In current scenario, LUP 2015 and NUDS 2017 remotely complement each other. There are more than enough existing acts and regulations related to land use planning, but due to lack of inter-departmental co-ordination, institutional fragmentation, and unnecessary duplication of responsibility in government mechanism, implementation of sustainable land management in contemporary issues of regional and urban planning has become a long, faraway and almost impracticable goal to achieve. The recent Land use Act 2019 again seems to be formulated in isolation from various other institutions or organizations related to land development works. The act is largely based on traditional usage of land resources such as agriculture, hazard or disaster risk, and environmentally sensitive zones, etc. whereas it has remained silent in case of urban expansion areas. Despite the concurrent problem of land acquisition in several projects of national pride, no any provisions for such scenarios has been suggested in the act.

From the multi-axial issues of institutional fragmentation among inter-linked bodies to necessity of special provisions in land management and land administration in places of national level projects, may it be devoid of justified parameters and indicators or tenacious attitude in encroachment of government and public land, the utmost tool for appropriate intervention is policy refining at last. But with astonishment, even policies are incoherent in context of land management in Nepal. As it has been discussed earlier that a new Land use Policy (LUP) was framed in 2015 subsequently retracting the NLUP 2013 of Nepal. Though both the policies are mostly similar, some strategically important appendices on definitions of land use from 2013 have been entirely removed from the 2015 version. In NLUP 2013, detailed in-clause basis and criterion for determination of 6 different definitions and zones for respective land use has been illustrated in Appendix No. 1. Whereas in the updated LUP 2015, the detailed appendix has been omitted with basic definitions of 11 different land use zones only. Whether this change was just an alteration or may it be intentional, such immaturity and inaccuracies in policy re-writing is more than likely invite obstacles in its implementation.

Apart from conventional policy interventions, some technical tools such as Computer-aided Designs (CAD), Building Information Modelling (BIM) Technology, appropriate use of 
Information and Communications Technology (ICT), Geoinformatics, and etc. can also bring about continuous evolution in land management and land administration as well. For instance, unnecessary fragmentation of land could be controlled by designing a special software for plot division which would be programmatically based upon pre-set parameters or bye laws related to land administration of given municipal area. Similar uses and advancement in Geographic Information System (GIS) software can also assist in digital land management and land administration services. Another important step to control and protect land resources for future urban expansion is that an autonomous body such as former TDCs or an independent planning commission having legal rights with single-door system of operation be reformed in each local levels which would devise, regulate and monitor overall structure plan of particular local authority aimed at regional and urban planning and subsequent development.

\section{CONCLUSIONS}

There is an urgent need of an integrated act on land use planning which would contain mutual aspects of both socio-economic and physical dimensions in land management and land administration, and in regional and urban planning sector. It comes as an important lesson from the case study of governance of land use in the Netherlands that the local land use plans be self-binding whereby local level government practices its own legislation independent to the federal government. This practice would be meaningful only if the local governments have attained required technical and institutional capacity with long-term vision for spatial development of their land resources. Likewise, from the case study of participatory land use planning and implementation, it is evident that community driven sustainable land management projects are prospective to become fruitful in sensitization of land use planning among the general public and local stakeholders Equally important is an integration of relevant building bye laws with rules and regulations of land administration of a municipal area. It is seen that nonprofessional land brokers and surveyors with limited knowledge of planning are involved in illegal plotting of land making it vulnerable to degradation in long run. This needs to be restricted and legal practice of land development must be assigned to planning professionals only.

As the research of this paper is particularly focused in relevancy of land use in land management, and regional and urban planning in Nepal, the study work is limited to general background and interdisciplinary aspects only rather than the explanation of broader concepts of land management, and regional and urban planning. Also, methodology of the research is based on constructive criticism on existing policy and implementation gaps with relevant literature review, and the presentation is more discussion-oriented rather than being result-oriented.

\section{REFERENCES}

Carl Pruscha, 2019. 1964 - 1974. Nepal Projects. (2 November 2019)

Central Bureau of Statistics \& The World Bank, 2013: NEPAL Small Area Estimation of Poverty, 2011: Summary and Major Findings, Government of Nepal (GoN) \& The World Bank, Kathmandu, Nepal.

Enemark, S., 2010. Land Management: A Global Perspective. Nepalese Journal on Geoinformatics, Vol. 9, 21-25.
Forest Research and Training Center, 2019: National Level Forests and Land Cover Analysis of Nepal using Google Earth Images, Ministry of Forests and Environment (MoFE), Kathmandu, Nepal.

House of Representatives Nepal, 2019. Validated Bills. Bill Related to Land use Management. hr.parliament.gov.np (2 November 2019).

Joshi, J., 2008: Planning Approaches in Nepal, Mrs. Lajmina Joshi, Kathmandu, Nepal.

Joshi, J., 2019: Urban Planning in Nepal: Approaching Sustainability, Mrs. Lajmina Joshi, Kathmandu, Nepal.

Ministry of Agriculture, Land Management and Cooperatives (MoALC), 2018: Fit-For-Purpose Land Administration (A Country Level Implementation Strategy For Nepal), Government of Nepal (GoN), Kathmandu, Nepal.

Ministry of Land Management, Cooperatives and Poverty Alleviation (MoLCPA), 2019. About Ministry. Historical Background. molcpa.gov.np (2 November 2019).

Ministry of Land Reform and Management (MoLRM), 2015: Land use Policy 2015, Government of Nepal (GoN), Kathmandu, Nepal.

Ministry of Urban Development (MoUD), 2015: Planning Norms and Standards 2015, Government of Nepal (GoN), Kathmandu, Nepal.

Ministry of Urban Development (MoUD), 2017: National Urban Development Strategy 2017, Government of Nepal (GoN), Kathmandu, Nepal.

Muzzini, E., Aparicio, G., 2013: Urban and Spatial Transition in Nepal: An Initial Assessment, The World Bank, Washington, D.C.

OECD, 2017: The Governance of Land use in the Netherlands: The Case of Amsterdam, OECD Publishing, Paris.

Sharma, R.K., 2012. Evolution of Land use Policy in Nepal. Nepalese Journal on Geoinformatics, Vol. 11, 16-21.

Shrestha, R., Zevenbergen, J., Masum, F., Banskota, M., 2017: Exploring the Potential of the Land Readjustment Approach in Allocating Land for Affordable Housing from the Market Legitimacy Perspective, The World Bank, Washington, D.C.

The Kathmandu Post (TKP), 2019: The government spent Rs230 million on buildings for squatters. Nobody moved in. News published in the national daily of Nepal, TKP on 25 July, 2019.

UN-Habitat Nepal, 2015: Participatory Land use Planning and Implementation in Designated Districts: Surkhet, Nawalparasi and Morang, UN-Habitat Nepal, Lalitpur, Nepal.

United Nations (UN), 2019. Sustainable Development Goals. About the Sustainable Development Goals. un.org (2 November 2019). 